\title{
Bal peteği ve Beton Çekirdek Malzemesine Sahip Cam/Epoksi ve Karbon/Epoksi Kompozit Tüplerinin Bası Davranışı
}

\section{Compressive Behavior of Glass/Epoxy and Carbon/Epoxy Tubes Having Core Material with Concrete and Honeycomb}

\author{
Mehmet Emin Deniz ${ }^{*}$ (1), Mehmet Beşir Altın ${ }^{2}$ (]) \\ ${ }^{1}$ Batman Üniversitesi Mühendislik-Mimarlık Fakültesi Makina Mühendisliği Bölümü, Batman, TÜRKiYE \\ 2 Batman Üniversitesi Fen Bilimleri Enstitüsü, Batman, TÜRKIYE \\ Sorumlu Yazar / Corresponding Author*: mehmetemin.deniz@batman.edu.tr
}

\author{
Geliș Tarihi / Received: 17.04.2020 Araștırma Makalesi/Research Article \\ Kabul Tarihi / Accepted: 22.06.2020 DOI:10.21205/deufmd.2021236717 \\ Atıfsekli/How to cite: DENIZ, M.E., ALTIN, M.B.(2021). Bal peteği ve Beton Çekirdek Malzemesine Sahip Cam/Epoksi ve Karbon/Epoksi \\ Kompozit Tüplerinin Bası Davranışı. DEUFMD, 23(67), 195-206.
}

\section{Öz}

Bu deneysel çalışmada, $\left[-45^{\circ} /+45^{\circ}\right]_{4}$ ve $\left[0^{\circ} / 90^{\circ}\right]_{4}$ gibi iki farklı dizilim açısına sahip cam/epoksi ve karbon/epoksi kompozit kare tüplerin K25Y30, K50Y60 ve K100Y120 olarak üç farklı boyutta elle yatırma yöntemi kullanılarak üretimi gerçekleştirilmiştir. Üretilen kompozit tüpler için dolgu (çekirdek) malzemeleri olarak alüminyum bal peteği (honeycomb) ve C25 sınıflı hazır beton kullanılmıştır. Deneysel çalışmanın amacı, kompozit kare tüplerin eksenel bası davranışı üzerine numune boyutu, elyaf malzemesi tipi, dizilim açısı, dolgu malzemesi gibi parametre etkilerinin belirlenmesidir. Deney sonrası kompozit kare tüplerde oluşan deformasyon şekilleri yorumlandı. Dolgu malzemelerin yapısal ve dayanım özelliklerinin kompozit tüplerin bası davranışı üzerindeki etkileri araștırıldı. Tüm parametreler için elde edilen sonuçlar, kendi içinde ve birbirleriyle karşılaştırıldı. Dolgu malzemesi, her üç numune boyutunun bası davranışını iyileştirdiği görülmüştür. Numune boyutu büyüdükçe basma kuvveti değeri de artmıştır. En yüksek basma kuvveti beton dolgulu karbon/epoksi esaslı kompozit tüp numunelerde, en düşük değer ise içi boş cam/epoksi numunelerde meydana gelmiştir. Basma sonrası numune hasarları dizilim açısı yönünde oluşmuştur.

Anahtar Kelimeler: Bal peteği, bası davranışl, cam fiber, epoksi, karbon fiber

\begin{abstract}
In this experimental study, the production of glass/epoxy and carbon/epoxy composite square tubes with two different orientation angles such as $\left[-45^{\circ} /+45^{\circ}\right]_{4}$ and $\left[0^{\circ} / 90^{\circ}\right]_{4}$ in three different sizes as K25Y30, K50Y60 and K100Y120 was carried out by hand lay-up method. For produced the composite tubes, aluminum honeycomb and C25 class ready mixed concrete are used as filling materials. The purpose of the experimental study is to determine the parameter effects such as specimen size, fiber material type, orientation angle, filling material on the axial compression behavior of composite square tubes. After the experiment, deformation shapes in composite square tubes were interpreted. The effects of structural and strength properties of filler materials on compressive behavior of composite tubes were investigated. The results obtained for all parameters
\end{abstract}


DEÜ FMD 23(67), 195-206, 2021

were compared within themselves and with each other. The filling material was seen to improve the compressive behavior of all three specimen sizes. As the specimen size increased, the compression force value also increased. The highest compression force occurred in the composite tube specimens based on carbon/epoxy filled with concrete, and the lowest value was in hollow glass/epoxy specimens. Specimen damages after compression occurred in the direction of the orientation angle.

Keywords: Honeycomb, compression behavior, glass fiber, epoxy, carbon fiber

\section{Giriş}

Daha az ağırlık, artan mukavemet ve sertlik ile belirlenebilen geliştirilmiş performans için artan talep ile geleneksel malzemelerin yerini alan hafif kompozit malzemeler kullanılmaya ihtiyaç duyulmaktadır. Tamamen farklı fiziksel veya kimyasal özelliklere sahip en az iki farklı bileşen kullanılarak, birleștirildiğinde tek tek bileșenlere göre benzersiz özelliklere sahip bir malzeme üretilir [1]. Kompozitler, sürekli bir faza gömülmüș, bir veya daha fazla süreksiz fazdan oluşur. Süreksiz faz, genellikle sürekli fazdan daha sert ve daha güçlüdür, bu yüzden takviye veya takviye malzemesi olarak adlandırılır, sürekli faz ise matris olarak adlandırılır. Kompozitlerin özellikleri, bileșenlerin özelliklerine, dağılımlarına ve aralarındaki etkileşime güçlü bir şekilde bağlıdır [2]. Cam fiber takviyeli polimer kompozitlerde takviye (donatı) tipinin, yüksek mukavemeti ve betona hemen hemen benzer elastikiyet modülleri nedeniyle kirişlerde, plakalarda, kiriş-kolon bağlantılarında ve duvarlarda kullanımının etkili olduğu görülmüștür [3, 4]. Cam fiber takviyeli polimer kompozit çubukların iç takviye olarak kullanımı beton yapılarda dayanıklılık performansını iyileştirdiği görülmüştür [5]. Boylamasına cam fiber takviyeli polimer çubukların sayısı ve çapı değiştirilerek içi boş beton kolonların eksenel bası etkisi araştırılmıștır. Cam fiber takviyeli polimer çubukların kullanılması, kolonların eksenel sertliğini ve sünekliğini arttırmıştır [6]. Karbon fiber tüplerle takviyeli alüminyum bal peteğin mekanik davranışını ve enerji absorpsiyonunu incelemek için yapılan çalışmada, spesifik enerji absorpsiyonu değerlerinin tüp sayısı arttıkça hızla arttığı görülmüștür [7]. Karbon/epoksi esaslı kompozit bal peteğinin bası davranıșında; bal peteği içindeki fiber miktarındaki daha fazla artış, yapıda artan gözeneklilik seviyelerine bağlı olarak mukavemet düşüşüne neden olmuştur [8]. İnce cidarlı silindirlerin çekirdek malzemesinin iki geometrisi için verilen yüzeylere göre iki deney tipi tasarlandı. Deney sonuçları Abaqus gibi bir sonlu elaman programı sonuçları ile karşılaştırıldı [9]. Altıgenlerin kenarlarını daha küçük boyutlarda değiştirerek yüksek enerji absorpsiyon kapasiteli ultra hafif yapıları geliștirmek için bal peteklerinin deneysel ve nümerik analizi yapılmıștır. Yapısal hiyerarşinin incelenmesi, kalınlığın hücre kenarı uzunluğuna oranın artmasından dolayı enerji absorpsiyonun arttığı görülmüştür [10]. Karbon fiber kompozit tüplerin eksenel basma özellikleri incelendi. Çalışmanın ana özelliği, ilk tetiklemenin, biri konik olmayan diğeri de konik olan tasarımıydı. Eğimli tasarım, ilk tetikleyicinin maksimum kuvvetini düşürdü ve basma işlemi sırasında tüpün spesifik enerji emilimini maksimuma çıkardı [11]. Yapıștırıcıyla bağlanan karbon fiber takviyeli polimer kompozitlerin bası davranışı deneysel ve nümerik olarak araștırılmıştır. Deneyde karbon fiber takviyeli polimerin, dıș tabakaların dıșa doğru büküldügünü ve iç katların içe doğru büküldügü gözlemlenmiștir. Nümerik analizde, maksimum yük veya numunede gözlenen çatlak șekilleri açısından deneysel veriler ile iyi bir uyum göstermiștir [12]. Bal peteği dolgulu kare karbon fiber takviyeli tüplere yapılan deneyde, petek dolgulu kare karbon fiber takviyeli plastik tüplerin enerji emiliminin, içi boș kare karbon fiber takviyeli plastik tüplerine kıyasla arttığı ancak alüminyum petek ile doldurulduğunda ağırlık verimliliğini yitirmiștir [13]. Bası kuvveti uygulanan kare karbon fiber takviyeli tüpler için yeni bir analitik model geliştirilmiștir. Analitik modelde deneysel bası yükü uygulanan tüplerin, çatlak yayılımı, çatlak oluşumu, enine kesme ve sürtünme altında büyük miktarda enerji absorpsiyonu kaydedilmiştir [14]. Alüminyum bal peteğinin bası davranıșı deneysel ve nümerik analizle tartışılmıştır. Sonuçlarda, daha küçük hücreli numunelerin daha yüksek enerji absorpsiyon seviyelerine sahip olduğu görülmüştür. Düzlem içi yönlerin, ana çekirdek parametrelerinin değişimi, düzlem 


\section{DEÜ FMD 23(67), 195-206, 2021}

dışı yönünden daha duyarlı olduğu gözlendi [15]. Cam fiber takviyeli alüminyum kafesli epoksi matrisli beş tabakalı silindirik kompozitler enine ve eksenel basma yüküne maruz bırakılmıștır. Polimer esaslı kompozite alüminyum kafes eklenmesi, enine ve eksenel basma deneyi sırasında doğrusal olmayan gerilme tepkisine neden olmuştur [16]. Alüminyum bal peteği dolgulu karbon fiber takviyeli plastik kare tüpün yanal düzlemsel basma ve eğilme tepkileri araştırılmıştır. Bal peteği dolgulu karbon fiber takviyeli plastik kare tüplerinin; enerji absorpsiyonu, spesifik enerji absorpsiyonunun ve bası kuvveti verimliliğinin, karbon fiber takviyeli plastik kare tüpün içi boş tüplere klyasla arttığı görülmüştür [17]. Karbon fiber takviyeli polimer tüplerinin enine bükülme altındaki yük taşıma ve enerji emme özelliklerinin, eksenel bası yüklemesi altındakilere göre çok daha düşük olduğu görülmüștür. Bu nedenle, yanal özellikleri iyileştirmek için daha yüksek dayanımlı dolgu malzemeler önerilmiștir [18]. Karbon fiber takviyeli polimerler; metalik malzemeler üzerinde yüksek sertlik ve enerji emilimi avantajları sağladıklarından çeşitli endüstriyel uygulamalarda yaygin olarak kullanılmaktadır [19]. Çok hücreli karbon fiber takviyeli tüpler ile alüminyum kare tüplerin basma yükü altında enerji emilimi araştırılmıştır. Sonuçlarda, karbon fiber takviyeli tüplerinin maksimum yük, spesifik enerji absorpsiyonun aynı hücrelere sahip alüminyum tüplerininkinden daha yüksek olduğu görülmüștür [20]. Beş hücreli karbon fiber takviyeli plastik-alüminyum alaşımlı hibrit tüplerin bası deneyleri ve nümerik analizi yapıldı. Beş hücreli karbon fiber takviyeli plastik-alüminyum alaşımlı hibrit tüpün spesifik enerji absorpsiyonu, bütünü oluşturan tüplerin spesifik enerji absorpsiyonu toplamından daha büyük elde edilmiştir [21]. Çok hücreli kare sütunlara bası kuvveti uygulanarak teorik ve nümerik olarak davranışları incelenmiştir. Çapraz kesitler enerji emilimi için en verimli bileșen olduğu görülmüștür. Ayrıca kesit $3 \times 3$ hücreye bölündüğünde bir sütunun enerji emme verimliliği $\% 50$ artırılabilir [22]. Cok hücreli tüplerin deneysel ve nümerik analizi yapılmıştır. İç içe gömülmüş çok hücreli tüplerinin ortalama basma kuvveti, tüm bileşen tüplerin ortalama basma kuvvetlerinin basit toplamından daha büyüktür. Tüplerin performansı, ilişkili parçalar arasındaki bağlanma derecesiyle ilişkilidir [23]. Dairesel tüplerle doldurulmuş bal peteği hücreleri ile birleşik doldurulmuş petek hücrelerinin yeni bir modeli ortaya konulmuştur. Analizlerde dairesel tüplerle doldurulmuş petek hücreleri yapısının, geleneksel oyuk bal peteği çekirdeği ile aynı mükemmel mekanik özellikleri sağlamakla kalmayıp, aynı zamanda enerji emiliminde de belirgin bir üstünlük sağlamıştır [24]. Ticari altıgen alüminyum petekler, yüksek spesifik mukavemet, sertlik ve enerji emme kapasiteleri nedeniyle, havacilık ve uzay mühendisliğinde sandviç yapıların çekirdeği olarak yaygın şekilde kullanılır $[25,26] .\left[ \pm 55^{\circ}\right]_{3}$ dizilim açılı E-cam/epoksi kompozit tüplerin 15, 20 ve 25 J gibi üç farklı darbe enerjilerinde düşey darbe yüküne maruz bırakıldıktan sonra eksenel basma yükü altındaki davranıșları üzerine deniz suyunun etkisi incelenmiştir [2729]. Eğrisel yüzeyli iki farklı dizilim açısına sahip 50, 65 ve 80 -mm uzunluğundaki kompozit plakların burkulma davranıșları üzerine ortasında bulunan deliğin çap etkisi araștırılmıştır [30]. Yazarlar yapmış oldukları çalışmalarda seçilen parametrelerin kompozit tüp ve plakların bası davranışı üzerine önemli etkilerinin olduğunu tespit etmişlerdir.

Literatürde verilen çalıșmalar, yapılan deneysel çalışma ile arasındaki ilişkiyi göstermek amacıyla verilmiștir. Bu deneysel çalıșmada, üç farklı boyuta sahip kare kesitli cam/epoksi ve karbon/epoksi esaslı polimer kompozit tüplerin içi boş, içi alüminyum bal peteği ve C25 sınıfi beton ile doldurularak eksenel yöndeki bası davranışları incelenmiștir.

\section{Materyal ve Metot}

Farklı numune boyutu, dizilim açısı ve elyaf tipi ile üretilen kompozit yapılara bası yükü uygulanarak, farklı geometriksel ve mekaniksel kombinasyonlara sahip kompozit yapıların bası dayanıklılığı performansını, enerji absorpsiyon değerlerini, numunede meydana gelen fiziksel özellikleri ve diğer parametreleri ortaya çıkarmak için bir deneysel çalışma yapılmıștır.

\subsection{Deney Numunelerin Üretimi ve Hazırlanması}

$\left[-45^{\circ} /+45^{\circ}\right]_{4}$ ve $\left[0^{\circ} / 90^{\circ}\right]_{4}$ gibi iki farkl dizilim açısına sahip cam/epoksi ve karbon/epoksi 


\section{DEÜ FMD 23(67), 195-206, 2021}

kompozit kare tüpler, K25Y30 (iç kenar uzunlukları $25 \mathrm{~mm}$ ve yüksekliği $30 \mathrm{~mm}$ ), K50Y60 (iç kenar uzunlukları $50 \mathrm{~mm}$ ve yüksekliği $60 \mathrm{~mm}$ ) ve K100Y120 (iç kenar uzunlukları $100 \mathrm{~mm}$ ve yüksekliği $120 \mathrm{~mm}$ ) olarak üç farklı boyutta üretilmesi için metal kalıplar kullanıldı. Şekil 1 ve Şekil 2' de detaylı olarak verilen kompozit numunelerin üretimi ve hazırlanması aşamaları şu şekilde gerçekleştirilmiştir. Öncelikle 300 gr $/ \mathrm{m}^{2}$ yoğunluğa sahip tek yönlü cam fiber kumaş ve $320 \mathrm{gr} / \mathrm{m}^{2}$ yoğunluğa sahip tek yönlü karbon fiber kumaş $\left(-45^{\circ} /+45^{\circ}\right)$ ve $\left(0^{\circ} / 90^{\circ}\right)$ tabakalama açlarında kesildi. Matris malzemesi olarak F-1564 epoksi ve F-3486 sertleștirici karıșımı kullanılmıștır. Epoksi ve sertleștirici karışımın kesilen fiber kumaşlara emdirilmesi işlemi sağlanmıștır. Daha sonra bu kumaşlar daha önce hazırlanmış metal kalıpların üzerine el yatırma yöntemi ile sekiz tabaka şeklinde sarılmıştır. Üretimi gerçekleştirilen kompozit tüplerin kürleşmesi için oda sıcaklığında laboratuar ortamında 48 saat süreyle bekletilmiștir. Kürleșmeden sonra kompozit tüpler kalıptan çıkarılmıştır. En son işlem olarak numunelerin deneye uygun hale getirilmesi için uç kenarları kesim makinesinde düzeltilmiştir. Kenarları düzeltilen numunelerin $1 / 3^{\prime}$ lük bir kısmı içi boș, ikinci 1/3' lük kısmı $6,35 \mathrm{~mm}$ hücre boyutuna, $10 \mathrm{~mm}$ hücre yüksekliğine ve $0,5 \mathrm{~mm}$ hücre yüzey et kalınlığına sahip alüminyum bal peteği (honeycomb) kullanılarak içi doldurulmuştur. Kalan 1/3' lük son kısım ise C25 sınıfı hazır beton ile içleri doldurularak numunelerin deneye hazır hale getirilmesi sağlanmıştır. Bu şekilde her bir parametre için 3 numune olmak üzere toplam 108 numune hazırlanmıștır.

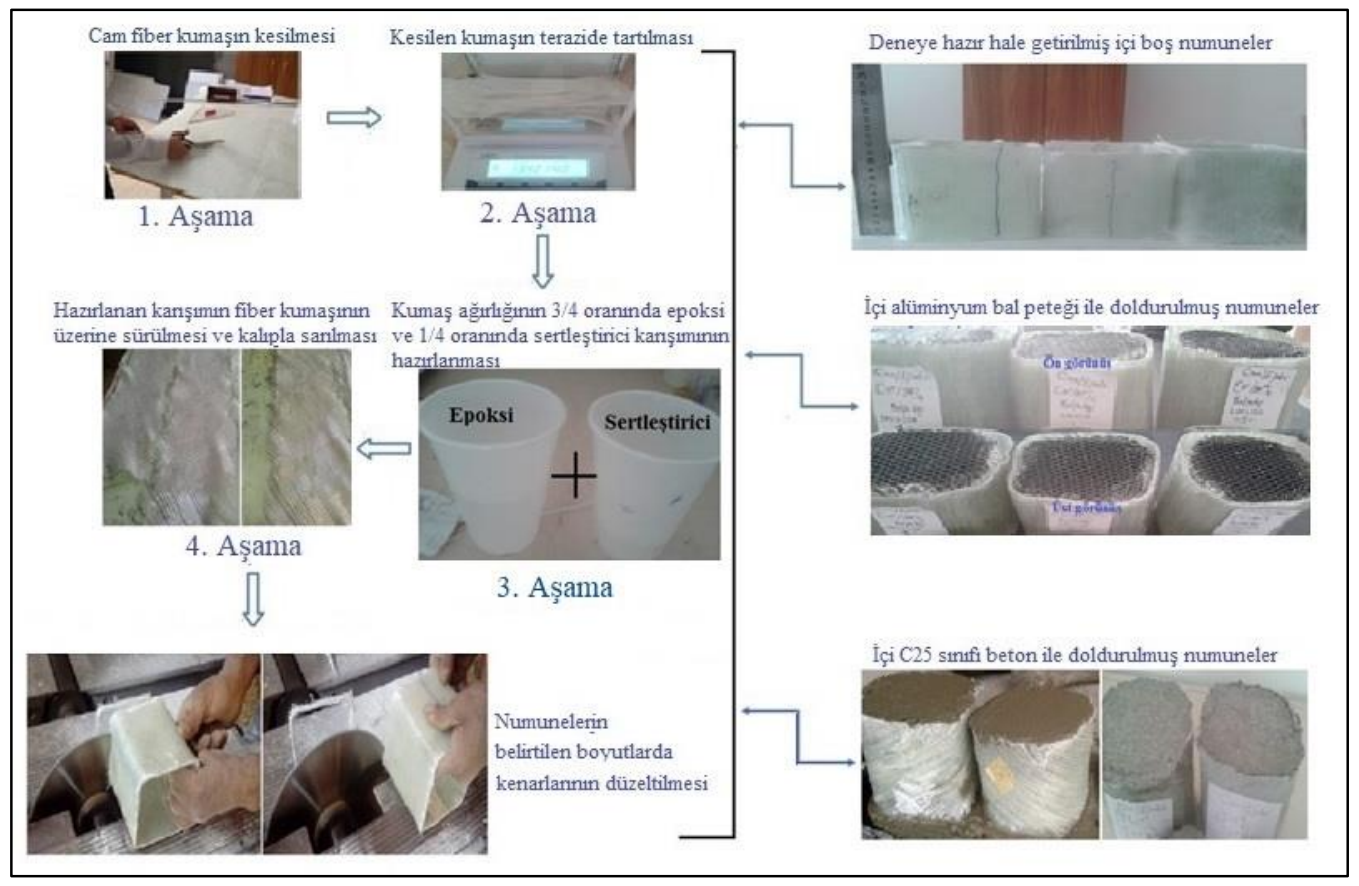

Şekil 1. Cam/epoksi kompozit tüp numunelerin hazırlanması 


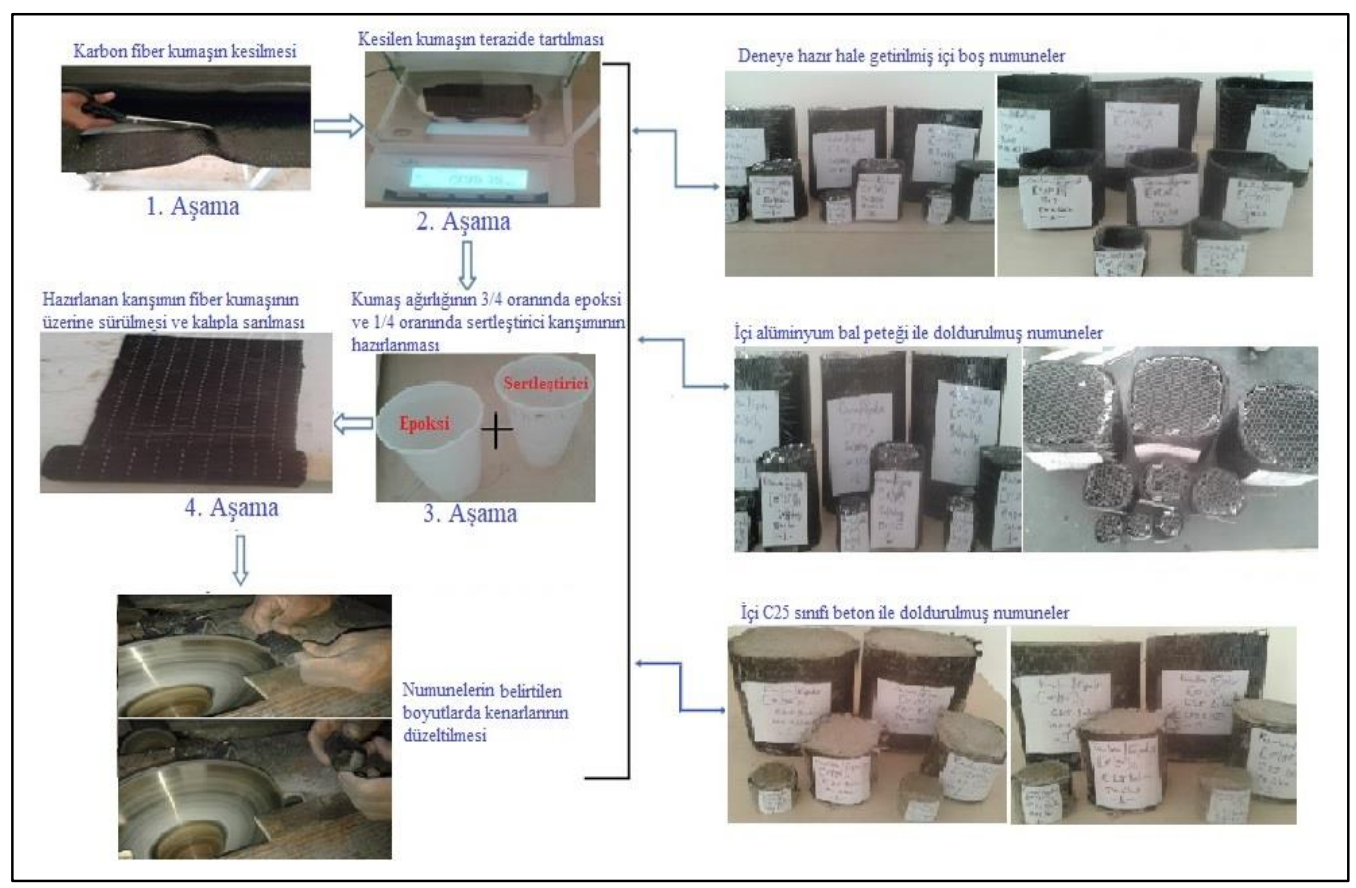

Şekil 2. Karbon/epoksi kompozit tüp numunelerin hazırlanması

\subsection{Deneyler}

Tüm deneyler, $250 \mathrm{kN}$ yük kapasiteli Shimadzu AG-IC marka üniversal çekme-basma deney cihazının basma özelliği kullanılarak oda sıcaklığında $1 \mathrm{~mm} /$ dak çene hızında yapılmıştır. Sonuçların değerlendirilmesi için üç numune değerinin ortalaması alınmıștır. Deney boyunca basma cihazı yük hücresi, kuvvet-çökme değerlerini kaydetmiştir. Şekil 3' te deney için hazırlanmış cam/epoksi numunelerin bir kısmı verilmiştir. Şekil 4' te ise karbon/epoksi numunelerin bazıları görülmektedir. Şekil 5' te verilen cihaz kullanılarak deneyler gerçekleștirilmiştir.
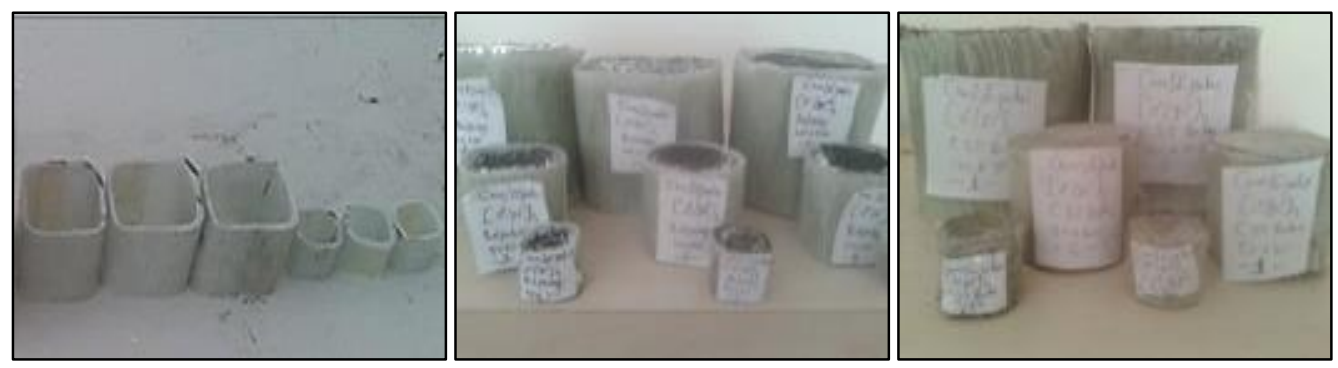

Şekil 3. Cam/epoksi deney numuneleri 

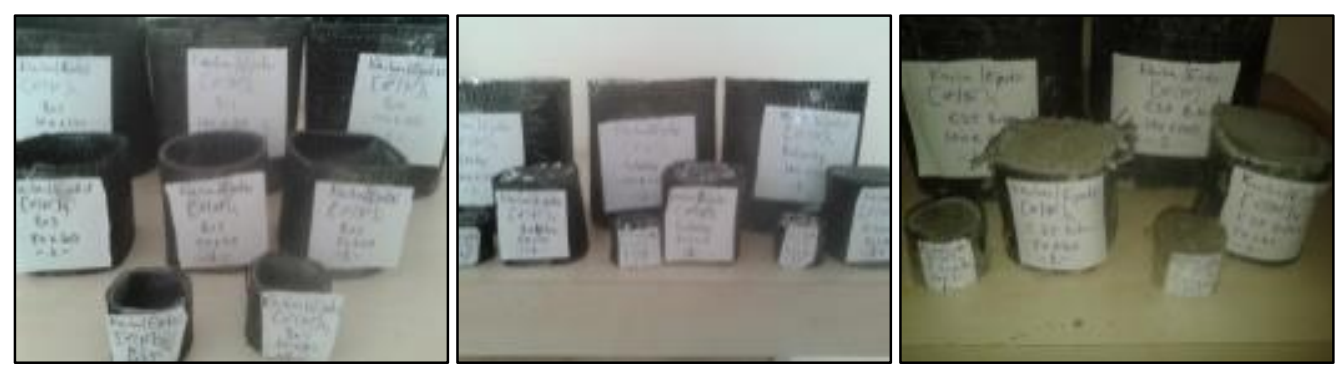

Şekil 4. Karbon/epoksi deney numuneleri

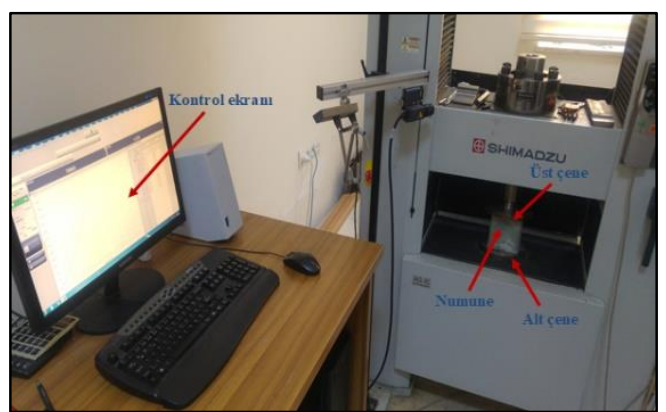

Şekil 5. Shimadzu AG-IC marka üniversal çekme-basma deney cihazı

\section{Bulgular}

Bu çalışmada, $\left[-45^{\circ} /+45^{\circ}\right]_{4}$ ve $\left[0^{\circ} / 90^{\circ}\right]_{4}$ dizilim açılarına sahip üç farklı boyutta cam/epoksi ve karbon/epoksi esaslı polimer kompozit tüpler kullanılarak tüplerin içi boş, içi bal peteği ve C25 sinuflı beton ile doldurulmuş numunelerin eksenel bası sonrası oluşan davranışlarının araștırılması hedeflenmiștir. Deney sonrası verilerin detaylı değerlendirilmesi için öncelikle örnek olması amacıyla $\left[0^{\circ} / 90^{\circ}\right]_{4}$ dizilim açısına sahip cam/epoksi numunelerin K25Y30, K50Y60 ve K100Y120 gibi üç farklı boyutu için kuvvet-çökme değerleri grafik eğrileri bir arada Şekil 6-8' de verilmiştir. Şekil 6, içi boș numunelerin verilerini göstermektedir. Grafik incelendiğinde kuvvet-çökme eğrileri, K25Y30 iki bölgeden oluşmaktadır. İlk bölgede eğri dik bir eğim ile yükselmektedir. Bu eğimin sonunda ilk hasar oluşmuştur. İkinci bölgede ise kuvvet belli bir değerde dalgalı șekilde değișmiștir. Burada ortalama basma kuvveti elde edilmiştir. K50Y60 ve K100Y120 için üç bölge görülmüştür. İlk bölge dik bir eğimle yükselmekte ve bu eğimin sonunda ilk hasar olușmuștur. İkinci bölgede Șekil 14 a ve Şekil $15 a^{\prime}$ da verildiği gibi hasarlı parçaların toplanmasından dolayı yükleme kuvveti artış göstererek eğri tekrar dik bir eğimle tırmanmıştır. Üçüncü bölgede ise eğriler, numuneler bası enerjisi absorbe ettiğinden dalgalı bir değișim göstermiştir. Numunelerin her üç boyutu için kritik (lokal) burkulma değerleri birbirlerine yakın elde edilmiştir. Değerler şu şekildedir: K25Y30 için 27200 N ve $1.89 \mathrm{~mm}, \mathrm{~K} 50 \mathrm{Y} 60$ için $23914 \mathrm{~N}$ ve $1.42 \mathrm{~mm}$ ve $\mathrm{K} 100 \mathrm{Y} 120$ için $28700 \mathrm{~N}$ ve 2.015 mm' dir. Final hasar (global burkulma) değerleri ise, K25Y30 için $32505 \mathrm{~N}$ ve $5.135 \mathrm{~mm}$, K50Y60 için 54531 $\mathrm{N}$ ve $2.95 \mathrm{~mm}$ ve K100Y120 için $72867 \mathrm{~N}$ ve $6.327 \mathrm{~mm}$ olarak elde edildi. Numune boyutları büyüdükçe ilk hasar (lokal burkulma) ve bası (final) hasarları değerleri yükselmiştir. Bir de numune boyutları artıkça hasar oluşumu gecikmiștir. Bunun sebebi büyük boyutlu numunelerinde deney esnasinda daha fazla enerji absorbe etmeleridir.

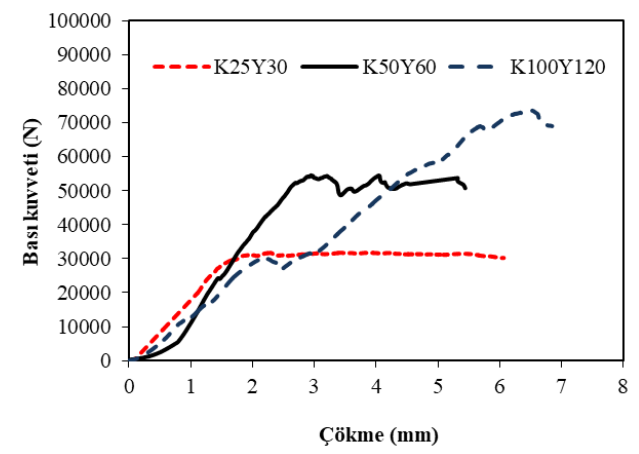

Șekil 6. $\left[0^{\circ} / 90^{\circ}\right]_{4}$ dizilim açısına sahip içi boș tüplerin bası kuvveti-çökme eğrileri 
İçi bal peteği dolgulu numunelere ait grafik eğrileri Şekil 7' de verilmiştir. Eksenel bası deneylerinden elde edilen basma kuvvetiçökme eğrileri iki bölgeden oluşmaktadır. İlk bölgede, eğriler dik bir eğimle tırmanmaya başlamıştır. $\mathrm{Bu}$ bölgenin sonunda numune hasarı oluşmuştur. İkinci bölgede ise eğriler, belli bir kuvvet değeri civarında dalgalı bir değişim göstermiştir. Bu bölgede, numune bası enerjisini absorbe etmiştir. Eğriler incelendiğinde, içi boş numunelerin eğrilerinden farklı durumların oluştuğunu söyleyebiliriz. K50Y60 ve K100Y120 numunelerde hasarlar diğer boyutlu numunelerden daha sonra başlamıştır. Bunun yanı sıra hasar değerleri içi boş numuneler ile kıyaslandığında benzer değerler elde edilmiștir. Fakat çökme miktarları daha fazladır. Bunun sebebi şöyle açılanabilir: petek dolgusu numunelerin burkulma hasarlarının görülmesini engelleyerek numunelerin daha yüksek çökme değerlerinde bası hasarının oluşmasını sağlamıștır.

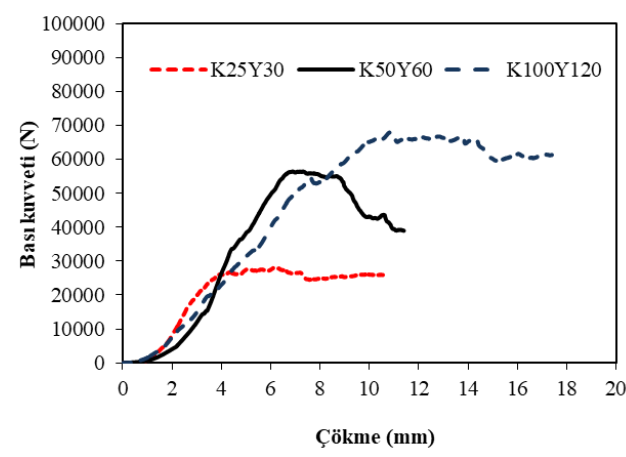

Şekil 7. $\left[0^{\circ} / 90^{\circ}\right]_{4}$ dizilim açısına sahip içi bal petek dolgulu tüplerin bası kuvveti-çökme eğrileri

Şekil 8' de verilen içi C25 sınıfı beton dolgulu numunelerin bası davranışı incelendiğinde, K50Y60 boyutlu numunenin bası yükleri diğer boyutların bası yüklerinden daha yüksek elde edilmiştir. Burada beton dolgusunun $\left[0^{\circ} / 90^{\circ}\right]_{4}$ dizilim açısına sahip kompozitlerin hasar davranışlarını iyileștirdiği görülmüştür. Ayrıca bu numunelerde lokal burkulma hasarının oluşmadığını görebilmekteyiz.

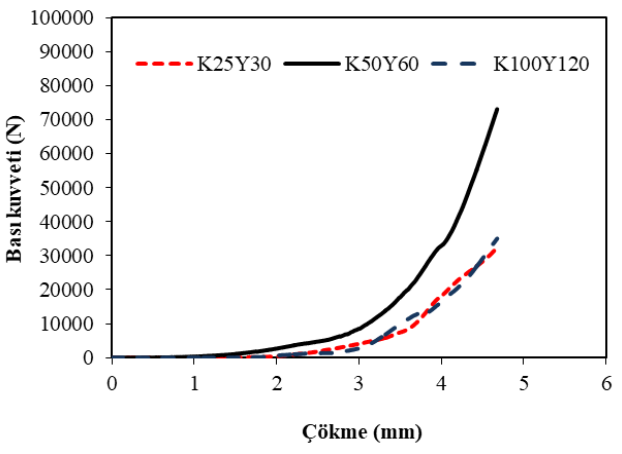

Şekil 8. $\left[0^{\circ} / 90^{\circ}\right]_{4}$ dizilim açısına sahip içi C25 sinıflı beton dolgulu tüplerin bası kuvvetiçökme eğrileri

Deney sonrası numunelerin basma kuvveti değişimleri incelendiğinde, numunelerin içinin boş olması ve dolu olması veya dolgu malzemesinin farklı olması basma davranışlarını önemli bir şekilde etkilediği görülmüştür. Şekil $9^{\prime}$ da $\left[0^{\circ} / 90^{\circ}\right]_{4}$ dizilim açısına sahip cam/epoksi numunelerin basma kuvveti üzerine dolgu malzemesinin etkisinin daha iyi anlașılması için numune boyutuna göre değişimi verilmiştir. Görüldüğü gibi dolgu malzemesinin değişimi basma kuvvetini değiștirmektedir. Burada numunelerin içinin boş olması ve dolgu malzemesinin değişimi için numune boyutu büyüdükçe kuvvet değeri de artmaktadır. Dolgu malzemesi numunelerin bası davranışını iyileştirmektedir. Bunun sebebi, içi boş numunelerin uçlarına yakın bölgelerde lokal burkulmaların meydana gelmesidir. Çünkü yük numune buyunca yayılmadığı için numunelerin bası direnci düşmektedir. Fakat dolgu malzemesi, yükü numunelerin orta bölgesine taşıdığı için bası direnci iyileşmektedir. Ayrıca numune boyutu artıkça dolgu malzemesinin etkisi daha belirgin görülmüştür. 
DEÜ FMD 23(67), 195-206, 2021

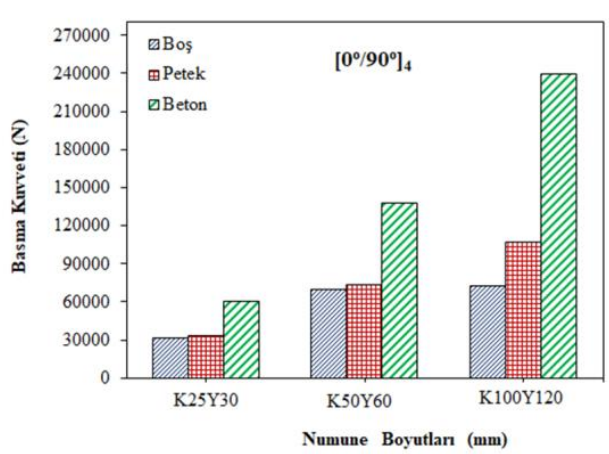

Şekil 9. $\left[0^{\circ} / 90^{\circ}\right]_{4}$ dizilim açısına sahip cam/epoksi tüplerin bası kuvvetinin numune boyutuna göre değişimi

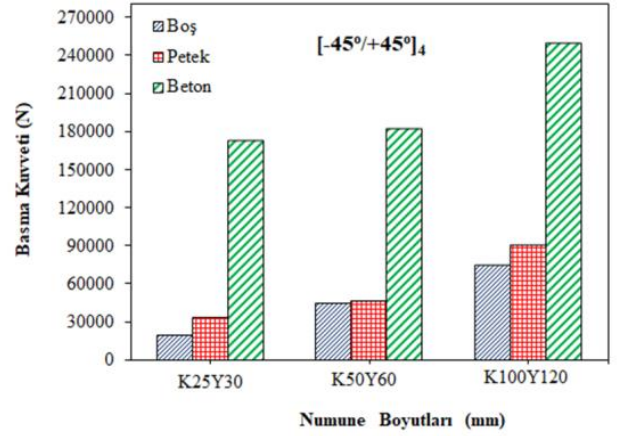

Şekil 10. $\left[-45^{\circ} /+45^{\circ}\right]_{4}$ dizilim açısına sahip cam/epoksi tüplerin bası kuvvetinin numune boyutuna göre değișimi

Şekil 11 ve Şekil 12' de verilen karbon/epoksi esaslı kompozit tüp numunelerde de cam/epoksi numunelerin davranışına benzer bir bası davranışı gösterdikleri açık bir şekilde görülmektedir. Şekil $11^{\prime}$ de $\left[0^{\circ} / 90^{\circ}\right]_{4}$ dizilim açll numunelerin ve Şekil $12^{\prime}$ de $\left[-45^{\circ} /+45^{\circ}\right]_{4}$ dizilim açllı numunelerin basma yüklerinin numune boyutuna bağlı olarak hem boş hem de dolgu malzemeleri için değişimi verilmiştir.

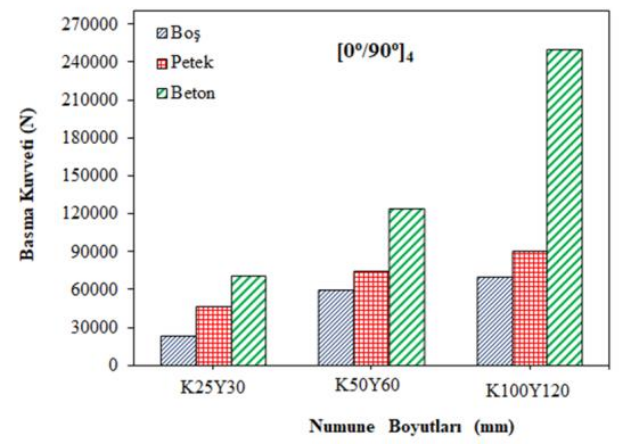

Şekil 11. $\left[0^{\circ} / 90^{\circ}\right]_{4}$ dizilim açısına sahip karbon/epoksi tüplerin bası kuvvetinin numune boyutuna göre değișimi

Șekil 10 ve Șekil 12' den görülebildiği gibi [$\left.45^{\circ} / 45^{\circ}\right]_{4}$ dizilim açısına sahip beton dolgulu numunelerin bası davranışı diğer numunelerin bası davranışlarından çok daha iyidir. Bunun sebebi gevrek yapıya sahip olan betonun basma yüküne karşı göstermiş olduğu dirençtir. Ayrıca numune boyutu, numunelerin bası davranışında az da olsa bir değişim etkisi göstermektedir. Her üç boyut için içi boş ve bal peteği dolgulu numunelerin bası davranışında $\left[0^{\circ} / 90^{\circ}\right]_{4}$ 
dizilim açısının $\left[-45^{\circ} / 45^{\circ}\right]_{4}$ dizilim açısından çok daha iyi bir dayanım sağladığını görebilmekteyiz.

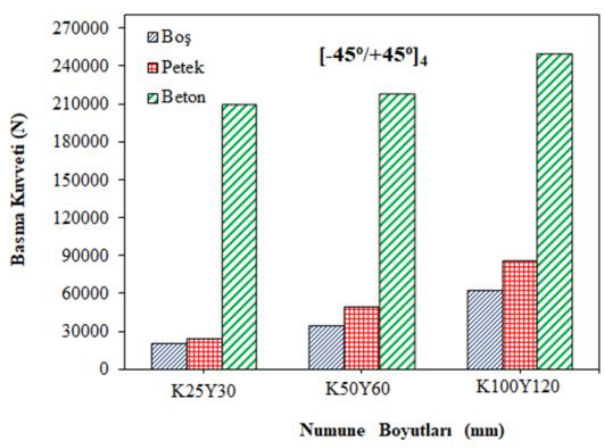

Şekil 12. $\left[-45^{\circ} /+45^{\circ}\right]_{4}$ dizilim açısına sahip karbon/epoksi tüplerin bası kuvvetinin numune boyutuna göre değișimi

Şekil 13 ve Şekil 14' te görüldüğü gibi bası sonrası hem içi boş tüplerde hem de içi beton dolu tüplerde oluşan çatlaklar fiberin dizilim açısı yönünde olduğu bu çatlakların büyümesiyle fiberlerin koptuğu ve numunede kalıcı hasarlar meydana geldiği görülmektedir.
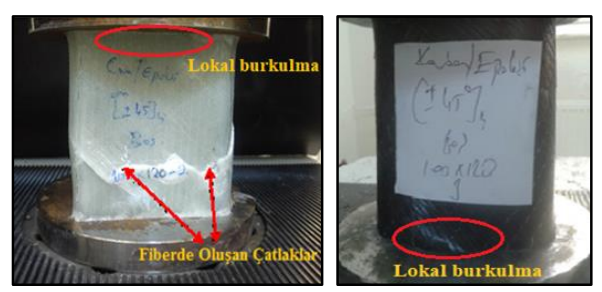

Şekil 13. K100Y120 boyutlu $\left[-45^{\circ} /+45^{\circ}\right]_{4}$ dizilim açılı cam/epoksi ve karbon/epoksi içi boș tüp numunelerin basma deneyi sonrası hasar durumları

Deneylerde basma kuvvetinin etkisinin belli bir kısmı kompozit kare tüp tarafında taşınarak tüpte çok az hasar meydana getirdiği, daha sonra basma kuvvetinin artmasıyla dolgu malzemeleri numune kenarlarını daha fazla sıkıştırarak numunelerin çatlamasına sonrasında yırtılmasına neden olmaktadır. Șekil 14' te iki dizilim açısına sahip K25Y30 boyutlu cam/epoksi içi boş, içi bal peteği dolgulu ve içi beton dolgulu kare kesitli tüp numunelerde oluşan deformasyon görüntüleri verilmiştir. Şekil 14a' da görüldüğü gibi hasar $90^{\circ}$ açıda gerçekleşirken Şekil 14b' de hasar $45^{\circ}$ açı yönünde oluşmuştur.
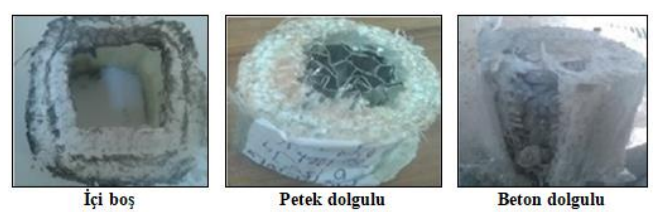

(a)
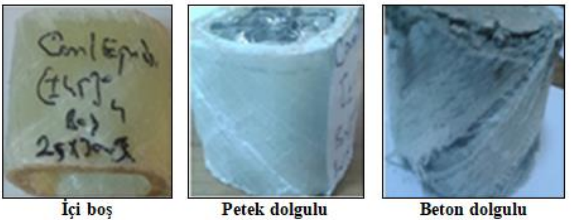

(b)

Şekil 14. K25Y30 boyutlu cam/epoksi kare tüpün bası sonrası deformasyon durumu; (a) $\left[0^{\circ} / 90^{\circ}\right]_{4}$ dizilim açıll, (b) $\left[-45^{\circ} /+45^{\circ}\right]_{4}$ dizilim açlı numuneler

Şekil 15' te K25Y30 boyutlu içi boş, içi bal peteği ve beton dolgulu karbon/epoksi tüp numunelerde oluşan deformasyon görselleri verilmiştir. Şekilden görüldüğü gibi bası hasarları dizilim açısı yönünde oluşmaktadır. Matris çatlağı, fiber kırılması ve tabakaların birbirinden ayrılması (delaminasyon) hasarları dizilim açısı yönünde gerçekleșmiştir. Deney esnasında numunelerin hasar biçimleri gözlemlendiğinde her iki takviye tipi için de $\left[0^{\circ} / 90^{\circ}\right]_{4}$ dizilim açılı numunelerde aynı oluşmuştur. Fakat numunelerin hasar biçimleri $\left[-45^{\circ} /+45^{\circ}\right]_{4}$ dizilimden farklı meydana gelmiştir. 


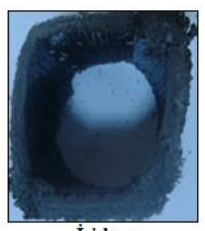

Ị̇ị boṣ

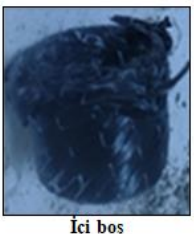

Iç̣i boṣ

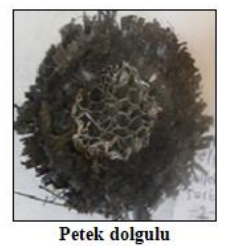

(a)

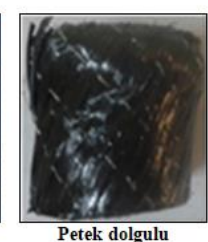

(b)
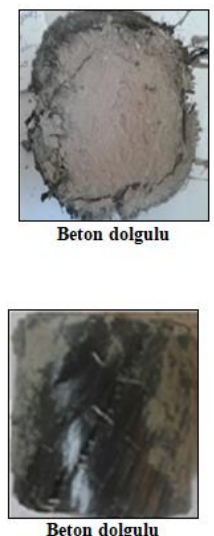

Beton dolgulu
Şekil 15. K25Y30 boyutlu karbon/epoksi kare tüplerde oluşan deformasyonlar; (a) $\left[0^{\circ} / 90^{\circ}\right]_{4}$ dizilim açılı, (b) $\left[-45^{\circ} /+45^{\circ}\right]_{4}$ dizilim açılı numuneler

Cam/epoksi ve karbon/epoksi esaslı kompozit tüplerin basma deneyi sonrasinda benzer șekilde hasara uğradıkları görülebilmektedir. Ayrica deney esnasinda $\left[-45^{\circ} /+45^{\circ}\right] 4$ ve $\left[0^{\circ} / 90^{\circ}\right]_{4}$ dizilimli numunelerde oluşan hasarlar birbirinden farklı olmuştur. Şekil 14 ve Şekil 15' te içi boş ve petek dolgulu numunelerin basma deneyi sonrasında basma yükünün uygulandığı uçta numune kenarında yayvan şeklinde bir hasar oluşmaktadır. Yani numunelerin içine ve dıșına doğru gövdeden bir kabuk gibi tabakaların eğilmesi ve numune boyunca nihai kırılma hasarının meydana gelmesidir. İçe doğru olan bu eğilme, numune içine kompozit parçalarının toplanmasına sebep olmuştur. Böylece deney esnasında ikinci bölgede yükleme kuvveti eğrileri dik bir eğimle tırmanış göstermiștir (Șekil 6). Tüm numuneler gevrek kırılma şeklinde hasara uğramıștır.

\section{Tartışma ve Sonuç}

Deney sonuçlarından cam/epoksi ve karbon/epoksi numunelerin içi bal peteği ve beton dolgulu olması numunelerin bası direncini arttırdığı görülmüștür. Özellikle kompozit tüplerin betonun dayanıklılığını arttırdığını, iyi bir malzeme güçlendirme etkisine sahip olduğu ve literatürdeki çalışmalarla benzer sonuçlar göstermiştir [3-6, 31-32]. Şekil 9-12' de içi bal peteği ve beton dolgulu cam/epoksi ve karbon/epoksi tüplerin maksimum bası direncini arttırdığ görülmektedir. Betonun bası direnci, bal peteği ile kıyaslandığında daha yüksektir. Bu yüzden, karbon/epoksi tüplerin betonun kullanıldığı uygulamalarda iyi bir güçlendirici etkisine sahip olduğu ve beton uygulamalarında kullanılabileceği net bir şekilde görülmüştür.

$\mathrm{Bu}$ çalışmada, farklı boyut ve dizilim açısına sahip, iki farklı fiber tipi ile üretilen kompozit yapıların bası davranışlarını incelemek için bir deneysel çalışma yapılmıştır. Elde edilen sonuçlar şu şekildedir:

$\checkmark$ Petek ve beton dolgulu numuneler, içi boş numunelerden daha iyi basma davranışı göstermiştir. Bunun sebebi dolgu malzemesinin varlığından dolayı numunelerin daha yüksek basma kuvveti değerlerinde bası hasarına uğramasıdır.

$\checkmark$ Kare tüpün boyutu arttıkça basma kuvveti değerlerinin arttığı görülmektedir. En yüksek basma kuvveti, karbon/epoksi esaslı $\left[-45^{\circ} /+45^{\circ}\right]_{4}$ dizilime sahip K100Y120 boyutlu beton dolgulu numunelerde meydana gelmiştir. En düşük basma kuvveti ise $\left[-45^{\circ} /+45^{\circ}\right]_{4}$ dizilime sahip cam/epoksi esaslı K25Y30 boyutlu boş numunelerde meydana gelmiştir.

$\checkmark$ Beton dolgulu cam/epoksi ile karbon/epoksi kare tüplerde maksimum deformasyon değerine ulaştığı, beton malzemenin bası direncini arttırdığını, beton dolgulu cam fiber ve karbon fiber takviyeli polimer kompozitlerin bina ve diğer yaplardaki betonun güçlendirilmesinde önemli katkı sunabileceği görülmüștür.

$\checkmark$ Beton dolgusunun etkisini bal peteği dolgusu ile kıyaslandığında yaklaşık iki katı daha yüksek etkiye sahiptir.

$\checkmark$ Ayrıca numune boyutu arttıkça basma kuvveti değerinin arttığı görülmüştür.

$\checkmark$ Hem dizilim açısı hem de takviye malzemesinin kompozit tüplerin bası davranışlarında önemli etkilerinin olduğu görülmüştür.

$\checkmark$ Her iki fiber tipi için bası hasarları tabakalama dizilim açısı yönünde gerçekleşmiştir.

\section{Alıntılanma ve Bildirim}

Bu çalışma, Batman Üniversitesi Fen Bilimleri Enstitüsü' de Mehmet Beşir ALTIN tarafından Doç. Dr. Mehmet Emin DENIZ danışmanlığında yapılan Yüksek Lisans Tez çalışmasından çıkarılmıştır. Bu çalışma yapılırken herhangi bir kamu veya ticari sektörden destek alınmamıștır. 


\section{DEÜ FMD 23(67), 195-206, 2021}

\section{Kaynakça}

[1] Pariti, V.N.P.M. 2017. Mechanical Behavior of Carbon and Glass Fiber Reinforced Composite Materials under Varying Loading Rates. University of Michigan, Master of Science Thesis, 131s, Dearborn.

[2] Shukla, S.P. 2011. Investigation into Tribo Potentia of Rice Husk (RH) Char Reinforced Epoxy Composite. National Institute of Technology, Deemed University, Master of Science Thesis, 103s, Rourkela.

[3] Abdul-Salam A., Farghaly, A.S., Benmokrane, B. 2016. Mechanisms of Shear Resistance of One-way Concrete Slabs Reinforced with FRP Bars, Construction and Building Materials, Cilt. 127, s. 959-970. DOI: 10.1016/j.conbuildmat.2016.10.015

[4] Ashour, A.F. 2006. Flexural and shear capacities of concrete beams reinforced with GFRP bars, Construction and Building Materials, Cilt. 20(10), s. 1005-1015. 10.1016/j.conbuildmat.2005.06.023

[5] Manalo, A., Benmokrane B., Park, K.P., Lutze, D 2014. Recent Developments on FRP Bars as Internal Reinforcement in Concrete Structures, Concrete in Australia, Cilt. 40(2), s. 46-56. http://eprints.usq.edu.au/id/eprint/26783

[6] Alajarmeh, O.S., Manalo, A.C., Benmokrane, B. Karunasena, W., Mendis, P., Nguyen, K.T.Q. 2019 Compressive Behavior of Axially Loaded Circular Hollow Concrete Columns Reinforced with GFRP Bars and Spirals, Construction and Building Materials, Cilt. 194, s. 12-23. DOI: 10.1016/j.conbuildmat.2018.11.016

[7] Al Antali, A., Umer, R., Zhou, J., Cantwell, W.J. 2017 The Energy-Absorbing Properties of Composite Tube-Reinforced Aluminum Honeycomb, Composite Structures, Cilt. 176, s. 630-639. DOI 10.1016/j.compstruct.2017.05.063

[8] Aziz, A.R, Kumar, S., George, P., Cantwell, W.J., Keller T., Yanes Armas, S., Carlsson, L.A., Frostig, Y. 2018 Energy-Absorbing Honeycomb Structures Based on Carbon Fiber Reinforced Plastics. 12th International Conference on Sandwich Structures ICSS-12, 19-22 August 2018, Lausanne, 178-180.

[9] Bigdeli, A., and Nouri, M.D. 2019. A Crushing Analysis and Multi-objective Optimization of ThinWalled Five-cell Structures, Thin-Walled Structures, Cilt. 137, s. 1-18. DOI: 10.1016/j.tws.2018.12.033

[10] Fang, J., Sun, G., Qiu, N., Pang, T., Li, S., Li, Q. 2018. On Hierarchical Honeycombs Under Out-of-Plane Crushing, International Journal of Solids and Structures, Cilt. 135, s. 1-13. DOI 10.1016/j.ijsolstr.2017.08.013

[11] Siromani, D., Awerbuch, J., Tan, T.M. 2014. Finite Element Modeling of The Crushing Behavior of Thin-Walled CFRP Tubes Under Axial Compression, Composite Part-B: Engineering, Cilt. 8, s. 50-64. DOI: 10.1016/j.compositesb.2014.04.008

[12] Han, X., Hou, S., Ying, L., Hou, W., Aliyev, H. 2019. "On The Fracture Behaviour of Adhesively Bonded CFRP Hat-Shaped Thin- Walled Beam Under Axial Crushing Load: An Experimental and Modelling Study, Composite Structures, Cilt. 215, s. 258-265. DOI: 10.1016/j.compstruct.2019.01.075
[13] Hussein, R.D., Ruan, D., Lu, G., Sbarski, I. 2016. Axial Crushing Behaviour of Honeycomb-Filled Square Carbon Fibre Reinforced Plastic (CFRP) Tubes, Composite Structures, Cilt. 140, s. 166-179. DOI: 10.1016/j.compstruct.2015.12.064

[14] Hussein, R.D., Ruan, D. and Lu, G. 2018. An Analytical Model of Square CFRP Tubes Subjected to Axial Compression, Composites Science and Technology, Cilt. 168, s. 170-178. DOI: 10.1016/j.compscitech.2018.09.019

[15] Ivanez, I., Canadas, L.F., Saez, S.S. 2017. Compressive Deformation and Energy-absorption Capability of Aluminum Honeycomb Core, Composite Structures, Cilt. 174, s. 123-133. DOI: 10.1016/j.compstruct.2017.04.056

[16] Ilangovan, S., Kumaran, S.S., Vasudevan, A. Surana, M. 2018. Investigation of The Transverse Compressive and Buckling Strength of Aluminum Grid Reinforced Hybrid GFRP Composite, Materials Today: Proceedings, Cilt. 5(11), s. 25625-25631. DOI: 10.1016/j.matpr.2018.11.002

[17] Liu, Q., Xing H., Ju Y., Ou, Z., Li Q. 2014. Quasi-static Axial Crushing and Transverse Bending of Double Hat Shaped CFRP Tubes, Composite Structures, Cilt. 117, s. 1-11. DOI: 10.1016/j.compstruct.2014.06.024

[18] Liu, Q., Ou, Z., Mo, Z.., Li, Q., Qu, D. 2015. Experimental Investigation into Dynamic Axial Impact Responses of Double Hat Shaped CFRP Tubes, Composites Part B: Engineering, Cilt. 79, s. 494-504. DOI: 10.1016/j.compositesb.2015.05.016

[19] Liu, Q., Xu, X., Ma, J., Wang, J., Shi, Y., Hui, D. 2017. Lateral Crushing and Bending Responses Of CFRP Square Tube Filled with Aluminum Honeycomb, Composites Part B: Engineering, Cilt. 118, s. 104115. DOI: 10.1016/j.compositesb.2017.03.021

[20] Liu, Q., Ma, J., He, Z., Hu, Z., Hui, D. 2017. Energy Absorption of Bio-Inspired Multi-cell CFRP and Aluminum Square Tubes, Composites Part B: Engineering, Cilt. 121, s. 134-144. DOI: 10.1016/j.compositesb.2017.03.034

[21] Yu, H., Shi, H., Chen, S. 2019. A Novel Multi-cell CFRP/AA6061 Hybrid Tube and Its Structural Multi Objective Optimization, Composite Structures, Cilt. 209, s. 579-589. DOI: 10.1016/j.compstruct.2018.10.112

[22] Zhang, X., Cheng, G., Zhang, H. 2006. Theoretical Prediction and Numerical Simulation of Multi-cell Square Thin-walled Structures, Thin-Walled Structures, Cilt. 44(11), s. 1185-1191. DOI: 10.1016/j.tws.2006.09.002

[23] Zhang, X., Leng, K., Zhang, H. 2017. Axial Crushing of Embedded Multi-cell Tubes, International Journal of Mechanical Sciences, Cilt. 131-132, s. 459-470. DOI: 10.1016/j.ijmecsci.2017.07.019

[24] Wang Z and Liu J. 2018. Mechanical Performance of Honeycomb Filled with Circular CFRP Tubes, Composites Part B: Engineering, Cilt. 135, s. 232241. DOI: $10.1016 /$ j.compositesb.2017.09.048

[25] Gibson L.J. and Ashby M.F. 1997. Cellular Solids: Structure and Properties. Cambridge University Press, 510s. DOI: 10.1017/CB09781139878326

[26] Lu, G. and Yu, T. 2003. Energy Absorption of Structures and Materials. Woodhead Publishing, $424 s$ 
DEÜ FMD 23(67), 195-206, 2021

[27] Deniz, M.E., Karakuzu, R., Sari, M., Icten, B.M. 2011. "On The Residual Compressive Strength of The Glass-Epoxy Tubes Subjected to Transverse Impact Loading, Journal of Composite Materials, Cilt. 46(6), s. 737-745. DOI: 10.1177/0021998311410483

[28] Deniz, M.E. (2011) "Seawater Effect on Behaviors of Impact and Axial Compression-After Impact of Composite Pipes. Dokuz Eylül Üniversitesi, Fen Bilimleri Enstitüsü, Doktora Tezi, 91s, İzmir.

[29] Deniz, M.E., Karakuzu, R., Icten B.M. 2013 Transverse Impact and Axial Compression Behaviors of Glass/Epoxy Pipes Subjected to Seawater and Impact Loading, International Journal of Damage Mechanics, Cilt. 22(7), s. 1071-1085. DOI: $10.1177 / 1056789513475687$

[30] Deniz, M.E. 2017. Buckling Behavior of Curved Composite Plates with a Central Circular Hole, Dicle University Journal of Engineering, Cilt. 8(1), s. 203212.

https://dergipark.org.tr/tr/pub/dumf/issue/33627 /398702

[31] Alajarmeh, O.S., Manalo, A.C., Benmokrane, B., Karunasena, W., Mendis, P. 2019. Axial Performance of Hollow Concrete Columns Reinforced with GFRP Composite Bars with Different Reinforcement Ratios, Composite Structures, Cilt. 213(1), s. 153164. DOI: $10.1016 /$ j.compstruct.2019.01.096

[32] Sun, H., Jia, M., Zhang, S., Wang, Y. 2019. 'Study of Buckling-Restrained Braces with Concrete Infilled GFRP Tubes', Thin-Walled Structures, Cilt. 136, s. 16-33. DOI:10.1016/j.tws.2018.10.040 